\title{
HAEMOPARASITES AND THE HAEMATO- BIOCHEMICAL PROFILES ASSOCIATED WITH ANAPLASMA MARGINALE INFECTIONS OF CATTLE IN ILORIN, NIGERIA
}

\author{
Shola David Ola-Fadunsin ${ }^{1 *}$, Isaiah Oluwafemi Ademola ${ }^{2}$, Johnson Olayide Adejinmi², \\ Babatunde Samuel Okediran ${ }^{3}$
}

${ }^{1}$ Department of Veterinary Parasitology and Entomology, Faculty of Veterinary Medicine, University of Ilorin, Ilorin, Kwara State, Nigeria.

${ }^{2}$ Department of Veterinary Parasitology and Entomology, Faculty of Veterinary Medicine, University of Ibadan, Ibadan, Oyo State, Nigeria.

${ }^{3}$ Department of Veterinary Physiology and Biochemistry, Faculty of Veterinary Medicine, University of Ilorin, Ilorin, Kwara State, Nigeria.

\section{"Corresponding author:}

Dr Shola David Ola-Fadunsin

Department of Veterinary Parasitology and Entomology, Faculty of Veterinary Medicine, University of Ilorin, Ilorin, Kwara State, Nigeria.

Phone: +2349060054605

ORCID: 0000-0002-2265-2494

E-mail: olafadunsin.sd@unilorin.edu.ng

Original submission:

07 May 2021

Revised submission:

16 August 2021

Accepted:

04 Septembar 2021

\begin{abstract}
Haemoparasitism is a major cause of economic loss in many cattle-producing countries of the world. This study is, therefore, aimed at determining the prevalence, patterns of infections and risk factors associated with haemoparasitic infections of cattle in Ilorin, Nigeria. It is also aimed at determining the effect of Anaplasma marginale infection on the haemato-biochemical profiles of White Fulani cattle. Blood samples were collected from 478 apparently healthy cattle from both farms and slaughterhouses. The collected blood samples were subjected to parasitological, haematological, and biochemical analyses. The study revealed the presence of six haemoparasites: Anaplasma marginale (25.3\%), Babesia bigemina (22.6\%), Babesia bovis (12.1\%), Trypanosoma sp. (8.6\%), Theileria sp. (7.1\%), and Anaplasma centrale (5.2\%). The haemoparasite species co-infections rate decreased with increase in the number of co-infections. Breed, body condition score, level of packed cell volume (PCV) and presence of ticks were the risk factors significantly associated $(\mathrm{p}<0.05)$ with the occurance of $A$. marginale infection, while breed, age, body condition score, physiological status, PCV and presence of ticks were significantly associated $(\mathrm{p}<0.05)$ with the occurrence of $B$. bigemina infection. Haemoglobin concentration, PCV, red blood cells $(\mathrm{RBC})$, mean corpuscular volume (MCV), mean corpuscular hemoglobin concentration (MCHC), albumin, blood urea nitrogen, calcium, glucose, total bilirubin, and total protein were the haematological and biochemical parameters significantly associated $(\mathrm{p}<0.05)$ with $A$. marginale infection in the White Fulani breed of cattle. The data obtained from this study should ultimately improve the cattle production sector for better profitability in Nigeria.
\end{abstract}

Keywords: Babesia bigemina, blood, Kwara State, prevalence, risk factors 


\section{INTRODUCTION}

Haemoparasitism remains persisting as the major challenge facing animal health, production and reproduction causing the destruction of red blood cells resulting in anaemia, icterus, anorexia, emaciation, reduced productivity, infertility and even death (Ola-Fadunsin et al., 2018; Abdullah et al., 2019). The negative effects of haemoparasitic infections in man and animals is a global phenomenon, occurring more in tropical and subtropical countries, including Nigeria (Wenyet al., 2017; Ola-Fadunsin et al., 2018).

Ruminants are susceptible to a large number of parasites belonging to the three different groups: helminths, arthropods and protozoa (Hunter-Cevera and Belt, 1996). Among the various economically important bovine diseases, vector-borne haemoparasitic infections such as anaplasmosis, babesiosis, ehrlichiosis (cowdriosis), mycoplasmosis, theileriosis and trypanosomosis are recognized as a major cause of severe clinical illnesses in cattle (Haque et al., 2012; Ola-Fadunsin, 2017a; Ola-Fadunsin et al., 2018).

Haemoparasitic infections may be silent and only evident when the host is undergoing a clinical response to infection. While low-grade parasitaemia may be readily observed in blood smears from apparently healthy animals, heavy infection may inflict losses to the cattle industry due to the increase in mortality, reduced growth rate and production, lowered working efficiency and abortions (Sajid et al., 2007; Yitayew and Samuel, 2015).

Livestock (including cattle) farming is one of the most important sectors representing a valuable asset in both traditional and modern agriculture in sub-Saharan Africa, as well as in other tropical and subtropical counties of the world, providing milk and beef during festivities around the world, employment, hides and skin for leather production, flexible income for family units, manure, and farm energy (Bisimwa et al., 2018; Ola-Fadunsin et al., 2020).

Nigeria is the biggest livestock producer in sub-Saharan Africa, with a total population of 13.9 million cattle, and a greater number of this population is concentrated in the northern part of the country (Lawal-Adebowale, 2012). Despite the nation's indigenous population, a large number of cattle are imported from surrounding African countries to meet the increasing demands of beef in major cities in Nigeria (Adedipe et al., 2014). The White Fulani (Bunaji) breed is the most numerous breed of cattle in Nigeria and West Africa (Tawah and Rege, 1996; Kubkomawa, 2017).

In spite of the major concern and economic drawbacks caused by bovine haemoparasites, there is a lack of new published information about the prevalence and risk factors associated with haemoparasitic infections of cattle in Nigeria, and this study appears to be the first in Ilorin, Kwara State to shed light on the subject matter. The aim of this study was to determine the prevalence, patterns of infections and risk factors associated with haemoparasites of cattle in Ilorin and also to determine the effect of Anaplasma marginale on the haemato-biochemical profiles of White Fulani cattle. The findings from this study should enrich the national database on cattle haemoparasites and its disease surveillance, which is extremely important in the cattle management to improve production. 


\section{MATERIALS AND METHODS}

\section{Study location}

This study was carried out in Ilorin (which comprises Ilorin South, Ilorin West, and Ilorin East Local Government Areas). Ilorin is located almost in the middle of Nigeria, and hence, it is popularly referred to as the "connecting city of Nigeria". Ilorin is the capital (administrative) of Kwara State. The State is located between latitude $8^{\circ} 05 \mathrm{~N}$ and $10^{\circ} 15 \mathrm{~N}$, and longitude $2^{\circ} 73 \mathrm{E}$ and $6^{\circ} 13 \mathrm{E}$. It is located in the Middle Belt (North Central) within the forest-savanna region of Nigeria. The State is bordered in the west by Benin Republic, in the east by Kogi State, and the south by Ekiti, Osun, and Oyo States. Kwara State covers a total area of $34,500 \mathrm{~km}^{2}$ comprising rainforest in the south and wooded savannah in the larger part of the State. It has 16 local government areas. The state has a mean annual rainfall of between $112.8 \mathrm{~cm}$ and $146.9 \mathrm{~cm}$ and an average annual temperature ranging from $22.1{ }^{\circ} \mathrm{C}$ to $33.3^{\circ} \mathrm{C}$. It records a mean relative humidity of $49.6 \%$ (NBS, 2016; OlaFadunsin et al., 2020).

\section{Study population and sampling}

A total of 478 cattle were sampled from slaughterhouses and different cattle herds during a year period. A random sampling technique was used to select cattle for the study. Blood samples from 60 White Fulani cattle (31 free from $A$. marginale infection and 29 infected with $A$. marginale) out of the 478 sampled cattle, were used for the haematological and biochemical studies. The age of the sampled cattle was estimated, as described by Lasisi et al. (2002). Body condition scores (BCS) were recorded using the protocol as described by Shittu et al. (2014).

About $5 \mathrm{ml}$ of blood was collected either at slaughter (from the jugular) or from the coccygeal or jugular vein of adult cattle and calves, respectively. About $4 \mathrm{ml}$ of each sample was dispensed into a labeled plain test tube (that contains no anticoagulant) and the rest into a labeled test tube containing ethylenediaminetetraacetic acid as anticoagulant. The blood samples were then placed in a cool box and were transported to the Parasitology Laboratory of the Faculty of Veterinary Medicine, University of Ilorin, Nigeria for parasitological, haematological and biochemical analyses.

\section{Parasitological analysis}

Wet mount technique was carried out as described by Taylor et al. (2016). A drop of blood (about 20 $\mu 1)$ was placed on a clean glass slide, and covered with clean coverslip. This was examined for active parasites (trypanosomes) under the X10 objective of the microscope.

Thin blood smear was prepared using standard method as described by Cheesbrough (2006). A drop of blood was placed on one end of a clean, grease-free glass slide and made into thin film with aid of a spreader (a clean glass slide). This was done by allowing the spreader to touch the blood at an angle of $45^{\circ}$, and then spread gently but firmly along the surface of the horizontal slide so that the blood is dragged behind the spreader to form the film with a feathered edge. The prepared thin film was then air-dried, fixed in methanol for 2-5 minutes and stained in freshly prepared $10 \%$ Giemsa stain at pH $7.2(10 \mathrm{ml}$ Giemsa solution and $90 \mathrm{ml}$ buffer solution) for 25-30 minutes. Afterwards, the stained blood smear was rinsed in buffered water and allowed to dry. The smears were then examined at X100 objective magnification (oil immersion) on an Olympus Microscope for the presence and identification of haemoparasites, according to Soulsby (1986) and Shah-Fischer and Say (1989). 


\section{Determination of positivity}

Blood samples that were positive by one or both examination techniques were considered positive.

\section{Haematological and biochemical analyses}

Haematological parameters such as haemoglobin concentration, packed cell volume (PCV), red blood cell (RBC) count, and white blood cell (WBC) count were estimated from the noncoagulated blood samples as described earlier (Meyer and Harvey, 2004). The mean corpuscular volume (MCV) and mean corpuscular haemoglobin concentration (MCHC) were calculated using the values of the estimated $\mathrm{PCV}$, haemoglobin $(\mathrm{Hb})$ and RBC counts.

Serum extracted from the coagulated blood samples was subjected to biochemical analysis for estimating the levels of albumin, calcium, globulin, glucose, total bilirubin, total blood urea nitrogen (BUN) and total protein using standard procedures, as described by Thrall et al. (2012).

\section{Statistical evaluation}

All data collected from the study were recorded in a Microsoft Excel version 2016 spreadsheet. Statistical analyses were carried out using the Statistical Package for the Social Sciences (SPSS, Chicago, Illinois, USA) for Windows version 22.0. Descriptive statistics were conducted to estimate the prevalence using percentages in tables. The prevalence was calculated as the ratio between the number of cattle having an haemoparasite and the total number of sampled cattle. The univariate analysis (Chi-square) test and odds ratios (ORs) with $95 \%$ confidence interval (CI) were used to determine the association between each risk factor and the detected haemoparasites with more that $20.0 \%$ prevalence (A. marginale and Babesia bigemina). The ORs were calculated with respect to a reference category, as indicated in the respective tables. The haematological and biochemical data were analyzed using the One-Way Analysis of Variance (ANOVA). The values were statistically different when $p$ was $<0.05$.

\section{RESULTS}

A total of six species of haemoparasites were detected from the 478 cattle examined. These include A. marginale, B. bigemina, Babesia bovis, Trypanosoma sp., Theileria sp., and Anaplasma centrale (Figure 1). A. marginale was the most prevalent haemoparasite, recorded in $25.3 \%$ (121/478) of the cattle. A. centrale was the least prevalent, representing $5.2 \%$ of the sample population. The prevalence of the other detected haemoparasites ranged between $22.6 \%$ ( $B$. bigemina) and 7.1\% (Theileria sp.) (Figure 1).

A total of $59.0 \%$ of the cattle examined were infected with either one or more haemoparasites. The haemoparasite species co-infection chart did not show a normal distribution (Figure 2). Uninfected samples showed the highest prevalence (41.0\%), followed very closely by single species infections (40.6\%). The lowest co-infection was with four concurrent species $(0.2 \%)$. There was no five and six species co-infections.

Figure 3 shows the prevalence pattern of haemoparasitic infection and co-infections among sampled cattle in Ilorin, Kwara State. Of the total sampled cattle, $40.6 \%(95 \% \mathrm{CI}=36.3-$ 45.0) i.e. 194 animals were infected with single haemoparasite. Anaplasma marginale (12.8\%) was the most prevalent single haemoparasite infection, while $A$. centrale was the least with $2.5 \%$ prevalence.

There were nine combinations of double haemoparasitic infections among cattle with 
A. marginale + B. bovis combination been the most encountered with $5.0 \%(24 / 478)$ of the sampled population been affected. The prevalence for the triple co-infection pattern ranged between 1 to 3 occurrences with a prevalence of $0.2 \%$ to $0.6 \%$ and a 95\% confidence interval of $0.1-1.0$ and $0.2-1.7$. Theileria sp. + Trypanosoma sp. + A. marginale $+B$. bovis was the only four haemoparasite coinfection detected with a prevalence of $0.2 \%$ $(1 / 478 ; 95 \% \mathrm{CI}=0.1-1.0)$.

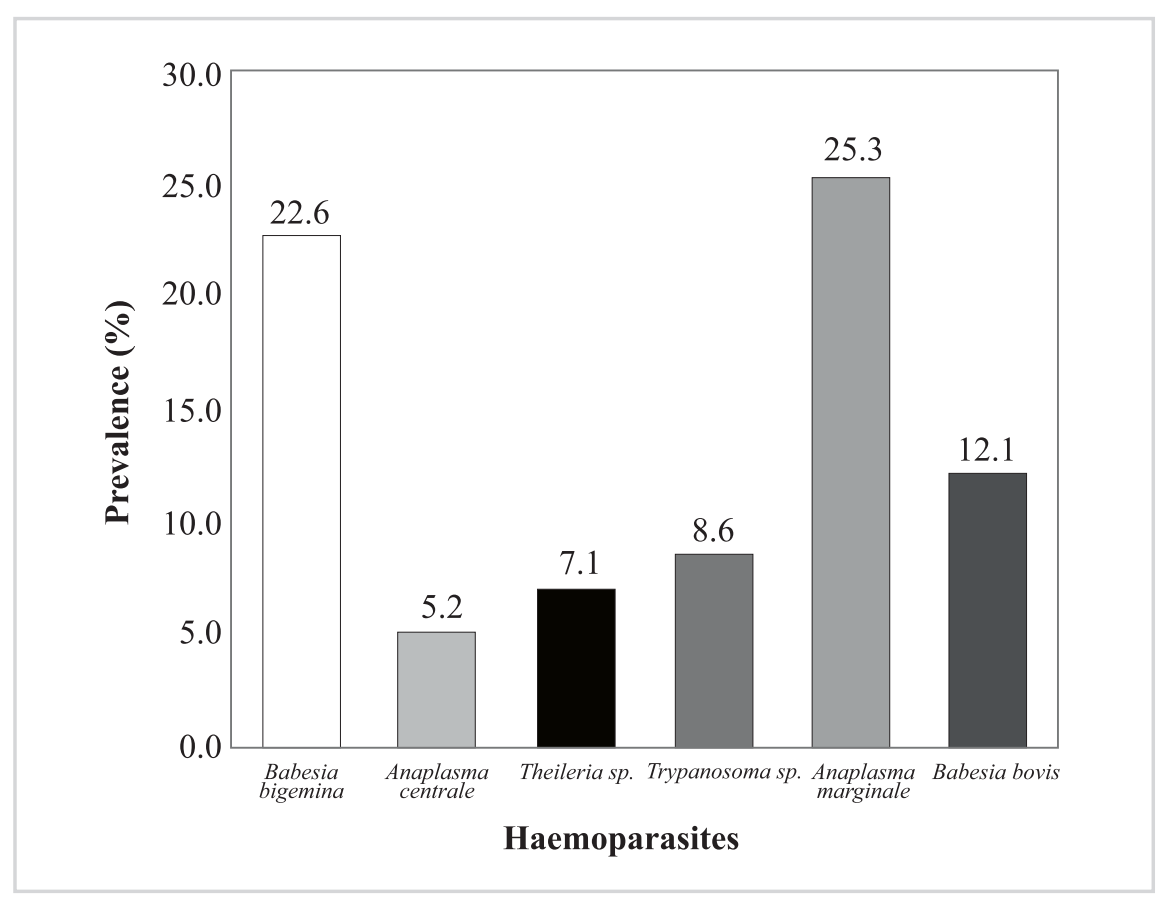

\section{Figure 1}

Prevalence of haemoparasites among cattle in Ilorin, Kwara State $(n=478)$.

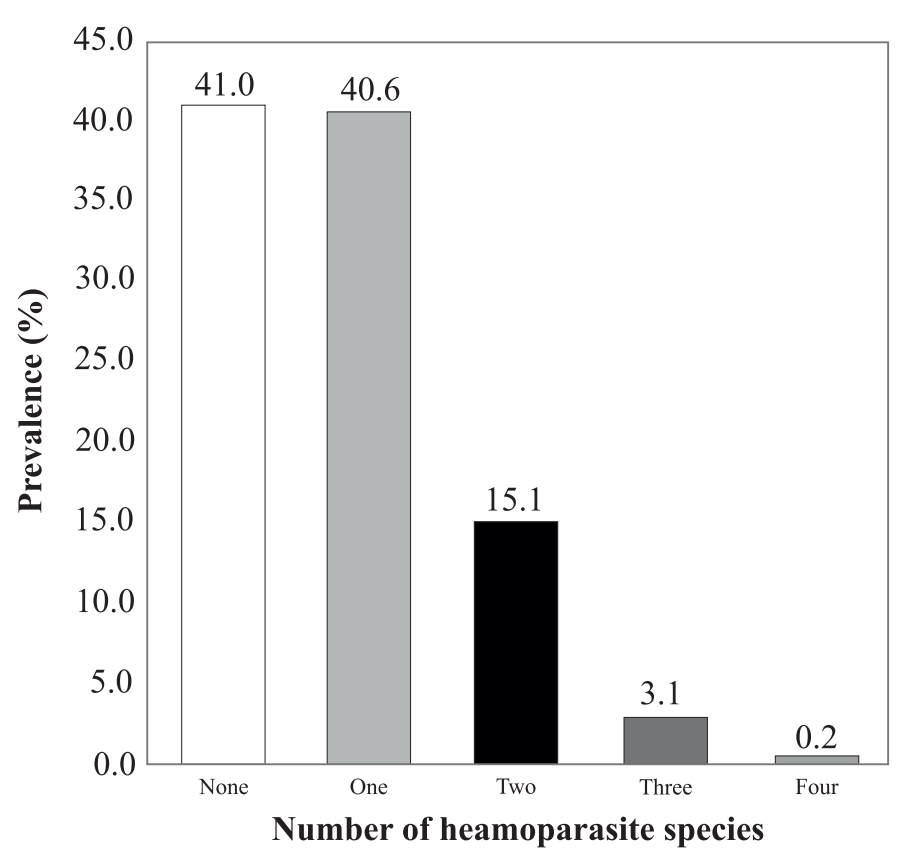

Figure 2

Prevalence of haemoparasites coinfections among cattle in Ilorin, Kwara State $(n=478)$. Single species infection recorded the highest prevalence, followed closely by double species co-infection. 


\section{Species}

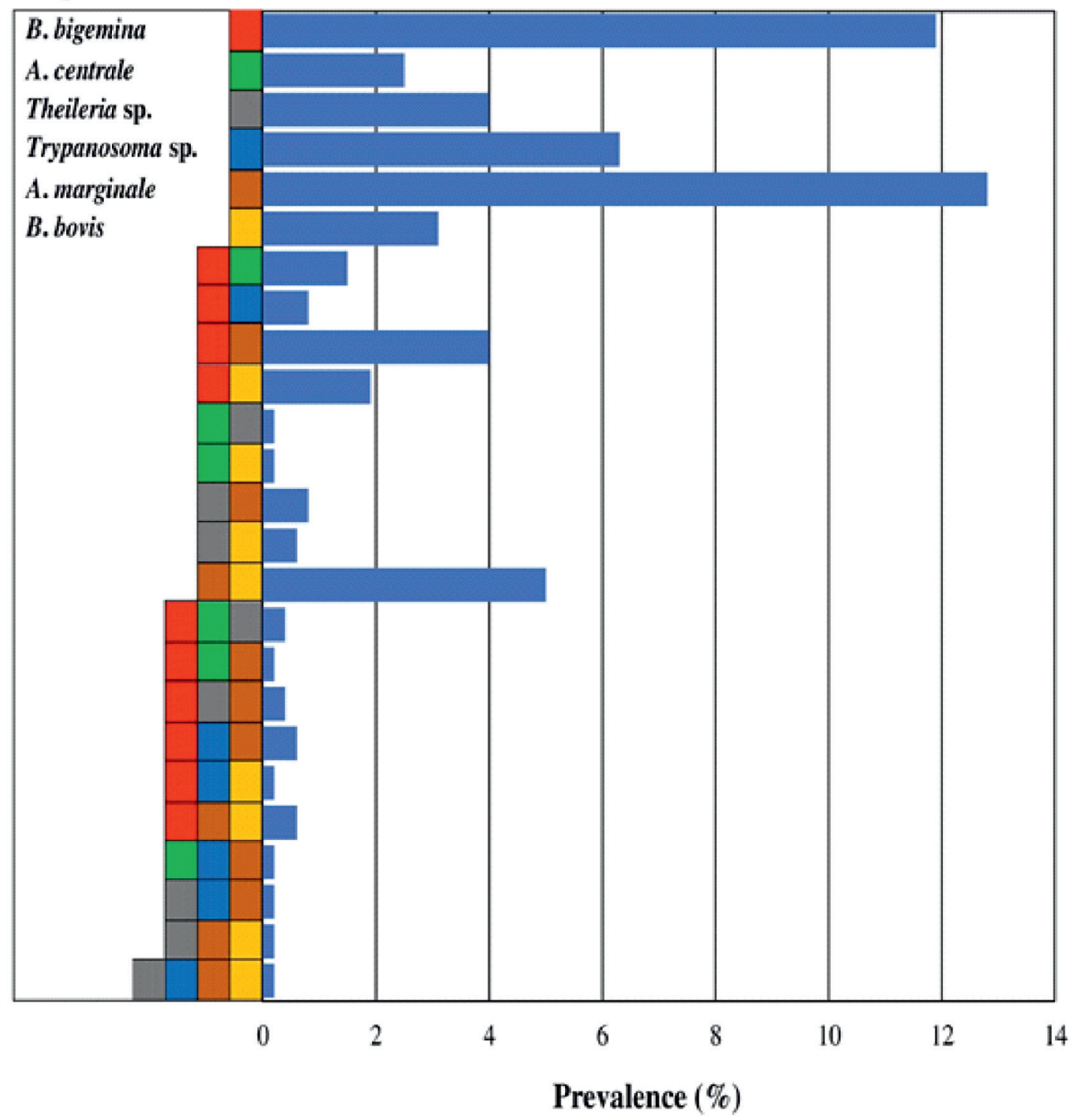

Figure 3 Prevalence of haemoparasite species co-infections among cattle in Ilorin, Kwara State. The various species and their combinations are represented by different colors as indicated in the left panel. 
The prevalence of $A$. marginale infection among the cattle examined was $25.3 \%(121 / 478)$. The univariate model revealed that breed, body condition score, PCV, and presence of ticks were significantly associated $(\mathrm{p}<0.05)$ with the infection. The prevalence of $A$. marginale was highest in the Friesian cross (93.8\%) compared to other cattle breeds. The lowest prevalence was recorded in the Keteku breed (10.4\%). Emaciated cattle were twice more likely to be infected with A. marginale compared to cattle with good body condition score. Anaemic cattle were about four times more likely to be infected compared to nonanaemic cattle. Cattle with tick infestation were 1.6 times more likely to be infected with $A$. marginale compared to cattle free from ticks (Table 1).

The association between the epidemiological variables and B. bigemina infection, showed that cattle breed, age, body condition score, physiological status, PCV and presence of ticks were significantly associated $(p<0.05)$ with the infection, while sex was not ( $p>0.05)$. The Friesian cross breed was most prone to the infection compared to the other breeds. The prevalence of $B$. bigemina decreased with an increase in the age of cattle, with cattle less than 1 year been 4.25 times more prone to the infection compared to cattle above 10 years old. The infection rate of B. bigemina was 3.26 higher in emaciated cattle compared to cattle with good body condition score.

Young cattle were most at risk of the infection $(\mathrm{OR}=3.49 ; 95 \% \mathrm{CI}=1.90-6.38)$ compared to non-physiologically active cattle. The infection was 3.65 times more in anaemic cattle compared to non-anaemic cattle. Cattle infested with ticks were about 5.5 times more likely to be infected with B. bigemina compared to cattle not infested with ticks (Table 2). 
Table 1 Univariate association between epidemiological variables and $A$. marginale infection among cattle in Ilorin, Kwara State.

\begin{tabular}{|c|c|c|c|c|}
\hline Risk factors & $\mathbf{N}$ & Positive (\%) & OR $(95 \%$ CI $)$ & p value \\
\hline \multicolumn{5}{|l|}{ Breed } \\
\hline Red Bororo & 104 & $29(27.9)$ & $0.03(0.01-0.16)$ & $<0.01^{\mathrm{a}}$ \\
\hline Sokoto Gudali & 74 & $23(31.1)$ & $0.03(0.01-0.19)$ & $<0.01^{\mathrm{a}}$ \\
\hline Kuri & 16 & $7(43.8)$ & $0.06(0.01-0.44)$ & $<0.01^{\mathrm{a}}$ \\
\hline Keteku & 48 & $5(10.4)$ & $0.01(<0.01-0.060)$ & $<0.01^{\mathrm{a}}$ \\
\hline White Fulani & 220 & $42(19.1)$ & $0.01(<0.01-0.09)$ & $<0.01^{\mathrm{a}}$ \\
\hline Friesian cross $*$ & 16 & $15(93.8)$ & 1.00 & \\
\hline \multicolumn{5}{|l|}{ Age (years) } \\
\hline$\leq 1$ & 40 & $13(32.5)$ & $1.40(0.61-3.15)$ & 0.41 \\
\hline$>1-\leq 4$ & 174 & $43(24.7)$ & $0.96(0.54-1.72)$ & 0.87 \\
\hline$>4-\leq 10$ & 170 & $41(24.1)$ & $0.93(0.52-1.68)$ & 0.80 \\
\hline$>10^{*}$ & 94 & $24(25.5)$ & 1.00 & \\
\hline \multicolumn{5}{|l|}{ Sex } \\
\hline Female & 430 & $110(25.6)$ & $1.12(0.58-2.44)$ & 0.71 \\
\hline Male* & 48 & $11(22.9)$ & 1.00 & \\
\hline \multicolumn{5}{|c|}{ Body condition score } \\
\hline Emaciated & 103 & $33(32.0)$ & $2.01(1.11-3.67$ & $0.02^{\mathrm{a}}$ \\
\hline Moderate & 238 & $62(26.1)$ & $1.50(0.90-2.55)$ & 0.12 \\
\hline Good* & 137 & $26(19.0)$ & 1.00 & \\
\hline \multicolumn{5}{|c|}{ Physiological status } \\
\hline Young & 57 & $12(21.1)$ & $0.82(0.40-1.61)$ & 0.60 \\
\hline Mating stock & 16 & $3(18.8)$ & $0.71(0.16-2.40)$ & 0.64 \\
\hline Pregnant & 11 & $5(45.5)$ & $2.56(0.70-9.00)$ & 0.15 \\
\hline Lactating & 80 & $24(30.0)$ & $1.32(0.76-2.26)$ & 0.32 \\
\hline Dry* & 314 & $77(24.5)$ & 1.00 & \\
\hline \multicolumn{5}{|l|}{ PCV } \\
\hline$\leq 24 \%$ & 147 & $65(44.2)$ & $3.88(2.52-6.01)$ & $<0.01^{\mathrm{a}}$ \\
\hline$>24 \% *$ & 331 & $56(16.9)$ & 1.00 & \\
\hline \multicolumn{5}{|l|}{ Presence of Ticks } \\
\hline Present & 307 & $87(28.3)$ & $1.59(1.02-2.52)$ & $0.04^{\mathrm{a}}$ \\
\hline Not present* & 171 & $34(19.9)$ & & \\
\hline
\end{tabular}

* Reference category, ${ }^{\text {a }}$ Significant, $\mathrm{OR}=$ Odds Ratio, $\mathrm{CI}=$ Confidence Interval. 
Table 2 Univariate association between epidemiological variables and B. bigemina infection among cattle in Ilorin, Kwara State.

\begin{tabular}{|c|c|c|c|c|}
\hline Risk factors & $\mathbf{N}$ & Positive (\%) & OR $(95 \%$ CI $)$ & p value \\
\hline \multicolumn{5}{|l|}{ Breed } \\
\hline Red Bororo & 104 & $26(25.0)$ & $0.15(0.04-0.48)$ & $<0.01^{\mathrm{a}}$ \\
\hline SokotoGudali & 74 & $14(18.9)$ & $0.11(0.03-0.36)$ & $<0.01^{\mathrm{a}}$ \\
\hline Kuri & 16 & $9(56.3)$ & $0.59(0.13-2.60)$ & $<0.01^{\mathrm{a}}$ \\
\hline Keteku & 48 & $17(35.4)$ & $0.26(0.07-0.85)$ & $<0.01^{\mathrm{a}}$ \\
\hline White Fulani & 220 & $31(14.1)$ & $0.08(0.02-0.23)$ & $<0.01^{\mathrm{a}}$ \\
\hline Friesian cross* & 16 & $11(68.8)$ & 1.00 & \\
\hline \multicolumn{5}{|l|}{ Age (years) } \\
\hline$\leq 1$ & 40 & $18(45.0)$ & $4.25(1.85-9.98)$ & $<0.01^{\mathrm{a}}$ \\
\hline$>1-\leq 4$ & 174 & $39(22.4)$ & $1.52(0.79-3.00)$ & 0.21 \\
\hline$>4-\leq 10$ & 170 & $36(21.2)$ & $1.41(0.73-2.81)$ & 0.31 \\
\hline$>10^{*}$ & 94 & $15(16.0)$ & 1.00 & \\
\hline \multicolumn{5}{|l|}{ Sex } \\
\hline Female & 430 & $92(21.4)$ & $0.55(0.29-1.06)$ & 0.07 \\
\hline Male* & 48 & $16(33.3)$ & 1.00 & \\
\hline \multicolumn{5}{|c|}{ Body condition score } \\
\hline Emaciated & 103 & $41(39.8)$ & $3.26(1.80-6.00)$ & $<0.01^{\mathrm{a}}$ \\
\hline Moderate & 238 & $44(18.5)$ & $1.12(0.65-1.98)$ & 0.69 \\
\hline Good* & 137 & $23(16.8)$ & 1.00 & \\
\hline \multicolumn{5}{|c|}{ Physiological status } \\
\hline Young & 57 & $24(42.1)$ & $3.49(1.90-6.38)$ & $<0.01^{\mathrm{a}}$ \\
\hline Mating stock & 16 & $5(31.3)$ & $2.18(0.66-6.46)$ & 0.18 \\
\hline Pregnant & 11 & $4(36.4)$ & $2.74(0.68-9.80)$ & 0.14 \\
\hline Lactating & 80 & $21(26.3)$ & $1.71(0.95-3.04)$ & 0.07 \\
\hline Dry* & 314 & $54(17.2)$ & 1.00 & \\
\hline \multicolumn{5}{|l|}{$\mathrm{PCV}$} \\
\hline$\leq 24 \%$ & 147 & $58(39.5)$ & $3.65(2.34-5.73)$ & $<0.01^{\mathrm{a}}$ \\
\hline$>24 \% *$ & 331 & $50(15.1)$ & 1.00 & \\
\hline \multicolumn{5}{|l|}{ Presence of Ticks } \\
\hline Present & 307 & $95(30.9)$ & $5.43(3.00-10.42)$ & $<0.01^{\mathrm{a}}$ \\
\hline Not present* & 171 & $13(7.6)$ & & \\
\hline
\end{tabular}

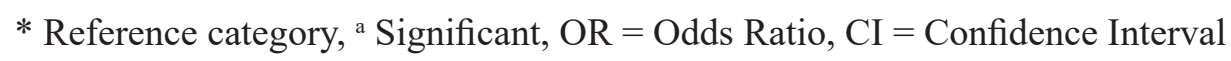


White Fulani cattle infected with $A$. marginale had a significantly lower $(\mathrm{p}<0.05)$ level of haemoglobin concentration, PCV and RBC count compared to cattle that were free from the blood parasite. There was no significant difference in $(\mathrm{p}>0.05)$ in the WBC count between the two groups of cattle. A. marginale infected cattle had a significantly higher mean corpuscular volume compared to $A$. marginale negative cattle, while the reverse was the outcome for the mean corpuscular haemoglobin concentration (Table 3). The level of total bilirubin and blood urea nitrogen was higher in cattle infected with $A$. marginale compared with those free from the parasite, and the difference was statistically significant $(p<0.05)$. There was a significantly higher level of albumin, calcium, glucose and total protein in A. marginale- free cattle compared to $A$. marginale infected cattle (Table 4).

Table 3 Mean haematological parameters between A. marginale negative and A. marginale positive White Fulani cattle in Ilorin, Kwara State.

\begin{tabular}{lcc}
\hline Haematological parameters & A. marginale negative $(\mathbf{n}=\mathbf{3 1})$ & A. marginale positive $(\mathbf{n}=\mathbf{2 9})$ \\
\hline $\mathrm{Hb}(\mathrm{g} / \mathrm{dL})$ & Mean $( \pm$ SEM $)$ & Mean $( \pm$ SEM $)$ \\
\hline $\mathrm{PCV}(\%)$ & $10.24(0.16)$ & $7.49(0.23)^{*}$ \\
\hline $\mathrm{RBC}(\times 106 / \mu \mathrm{L})$ & $32.48(2.19)$ & $27.11(2.70)^{*}$ \\
\hline $\mathrm{WBC}(\times 103 / \mu \mathrm{L})$ & $6.13(0.19)$ & $4.90(0.28)^{*}$ \\
\hline $\mathrm{MCV}(\mathrm{fL})$ & $8.89(1.29)$ & $7.92(1.21)$ \\
\hline $\mathrm{MCHC}(\mathrm{g} / \mathrm{dL})$ & $5.30(0.61)$ & $5.53(0.89)^{*}$ \\
\hline
\end{tabular}

*Significant $(\mathrm{p}<0.05), \mathrm{n}=$ Number of cattle, $\mathrm{SEM}=$ Standard error of mean, $\mathrm{Hb}=$ Haemoglobin, $\mathrm{PCV}=\mathrm{Packed}$ cell volume, $\mathrm{RBC}=\mathrm{Red}$ blood cell, $\mathrm{WBC}=$ White blood cell, $\mathrm{MCV}=$ mean corpuscular volume, $\mathrm{MCHC}=$ mean corpuscular haemoglobin concentration.

Table 4 Mean biochemical parameters between A. marginale negative and A. marginale positive White Fulani cattle in Ilorin, Kwara State.

\begin{tabular}{lcc}
\hline Biochemical parameters & A. marginale negative $(\mathbf{n}=\mathbf{3 1})$ & A. marginale positive $(\mathbf{n}=\mathbf{2 9})$ \\
\hline Albumin $(\mathrm{g} / \mathrm{dL})$ & Mean $( \pm$ SEM) & Mean $( \pm$ SEM $)$ \\
\hline BUN $(\mathrm{mg} / \mathrm{dL})$ & $3.20(0.28)$ & $2.51(0.39)^{*}$ \\
\hline Calcium $(\mathrm{mg} / \mathrm{dL})$ & $19.13(6.24)$ & $27.10(8.20)^{*}$ \\
\hline Globulin $(\mathrm{g} / \mathrm{dL})$ & $10.11(1.05)$ & $7.23(1.24)^{*}$ \\
\hline Glucose $(\mathrm{mg} / \mathrm{dL})$ & $2.71(0.36)$ & $2.48(0.32)$ \\
\hline Total bilirubin $(\mathrm{mg} / \mathrm{dL})$ & $60.17(1.82)$ & $51.06(1.45)^{*}$ \\
\hline Total protein $(\mathrm{g} / \mathrm{dL})$ & $0.78(0.14)$ & $1.24(0.18)^{*}$ \\
\hline
\end{tabular}

*Significant $(\mathrm{p}<0.05), \mathrm{n}=$ Number of cattle, SEM=Standard error of mean, BUN=Blood urea nitrogen 


\section{DISCUSSION AND CONCLUSION}

We reported $A$. marginale, $B$. bigemina, $B$. bovis, Trypanosoma sp., Theileria sp. and $A$. centrale as the haemoparasites affecting cattle in the study area. Similarly, Akande et al. (2010), Ademola and Onyiche (2013), Adua and Idahor (2017) and OlaFadunsinet al. (2018) had reported the presence of these blood parasites in different parts of Nigeria.

Also, these haemoparasites have been reported to affect cattle in Iraq (Abdullah et al., 2019), Uganda (Matovu et al., 2020) and Zambia (Tembo, 2012). This suggests that haemoparasites infections in cattle are a cosmopolitan phenomenon.

The high prevalence of $A$. marginale and $B$. bigemina observed in this study is in agreement with studies by Akande et al. (2010) and OlaFadunsin et al. (2018) conducted in Abeokuta, Ogun State and Jos Plateau States, respectively. The high prevalence of $A$. marginale observed in this study may be due to its transmission patterns, as $A$. marginale can be transmitted biologically by ticks or mechanically by biting flies such as Stomoxys calcitrans, Haematobia irritans and Tabanus spp., and by blood contaminated fomites (Taylor et al., 2016). Low prevalence of Theileria sp. and A. centrale among cattle has been documented in Nigeria by Okorafor and Nzeako (2014), Qadeer et al. (2015) and Ola-Fadunsin et al. (2018).

The overall prevalence $(59.0 \%)$ of cattle infected with one or more haemoparasites in this study is comparable to the $54.8 \%$ prevalence of haemoparasites infections reported among cattle in Nigeria (Atsuweet al., 2019) and the 53.0\% recorded in Thailand cattle (Kaewthamasorn and Wongsamee, 2006). Although it is lower than the 92.1\% prevalence documented among cattle in Malaysia (Ola-Fadunsin, 2017b), it is higher than the $11.7 \%$ total prevalence documented among cattle in Nigeria (Enogiomwan et al., 2019) and the $30.0 \%$ reported among cattle in Uganda (Wenyet al., 2017). The differences in the total prevalence observed in our study compared to other studies could be due to environmental factors, climatic factors, abundance of vectors (ticks and biting flies), and diagnostic methods used in the different studies.

In line with our finding, multiple haemoparasitic infections are a common phenomenon in cattle all over the world (Mahiza, 2010; Akande et al., 2010; Tembo, 2012; Ola-Fadunsin, 2017b; OlaFadunsin et al.,2018; Matovuet al., 2020). This may be associated with the fact that a tick species can serve as a vector and harbor more than one blood parasite at the same time.

The exotic cross breed of cattle (Friesian cross) showed a higher prevalence of both $A$. marginale and $B$. bigemina compared to the indigenous breeds of cattle. This responds to the work of Jonsson et al. (2008) and Carter (2011) who found that Bos taurus breeds and their crosses were more susceptible to A. marginale and B. bigemina compared to Bos indicus breeds. This may indicate that the local breeds of cattle have built resistance either to the vectors or parasites due to the long exposure over generations. Furthermore, acclimatization of the local breed to the local environment would render them hardier and more resistant to stressors that could predispose to infection.

The prevalence of $B$. bigemina decreases with age increase, i.e. older cattle had a significantly lower prevalence compared to the younger individuals, which is in agreement with previous reports (Sajid et al., 2014; Ola-Fadunsin et al., 2021). Possible reasons for younger animals may include a less developed immunity and lower disease resistance to the parasite and/or vectors (Sajid et al., 2014). 
Anaplasma marginale and B. bigemina have been documented to be associated with anaemia and weight loss (Taylor et al., 2016). This explains our observations where significantly higher prevalence of these haemoparasites was recorded in emaciated and anaemic cattle. The adverse effects (destruction of the RBCs, and anorexia, associated with infections) caused by $A$. marginale and $B$. bigemina, could be the reason for our findings.

The higher prevalence of $A$. marginale and $B$. bigemina seen in tick infested cattle is not surprising, as ticks are known to be the major vector associated with the transmission of these blood parasites in cattle (Kocan et al., 2004; Chauvin et al., 2009; Taylor et al., 2016).

A significant reduction in the haematological parameters $(\mathrm{Hb}, \mathrm{PCV}, \mathrm{RBC}$, and $\mathrm{MCHC})$ might be due to the intravascular haemolysis of erythrocytes, increased erythrocyte phagocytosis by the reticuloendothelial system, and restricted erythropoietic activity in the bone marrow which is a result of $A$. marginale infection (Ashuma et al., 2013). Anaplasma marginale infection was associated with anaemia, which was slightly macrocytic hypochromic in the infected cattle compared to the non-infected ones. There was rapid destruction of erythrocytes by the blood organism beyond what the spleen and bone marrow could cope, which resulted in anaemia. It is an indication that there was compensatory bone marrow response by early release of macrocytic, immature red blood cells into circulation. The hypochromicity may be due to non-fully haemoglobinated macrocytes in the circulation.

The reduction in total albumin and protein levels might be attributed to their decreased production due to the hepatic cell damage caused by the direct and indirect effects of Anaplasma species and the loss of appetite (anorexia) that is associated with the disease (Ganguly et al., 2018). The panhypoproteinaemia seen in the infected group compared to the non-infected group might be due to haemolysis observed in the infected group and massive loss of protein. The non-availability of nutrients may have also contributed to the panhypoproteinaemia. Acute phase of many infectious diseases has been associated with decrease of serum albumin value (Ganguly et al., 2018), with loss of appetite (anorexia) associated with reduced serum glucose level.

In line with our findings, high level of BUN has also been reported in cattle infected with $A$. marginale (Ganguly et al., 2018). The azotaemia observed may be a consequence of the globin metabolism, a protein generated from red cell haemolysis. The massive amino acids produced from globin were metabolized resulting in the production of ammonia which overwhelmed the liver in its conversion to urea. This azotaemia could also be due to alteration in the functionality of the liver or kidney resulting in perturbation of calcium metabolism resulting in the hypocalcaemia observed in this study. The hypoglycaemia may be as a result of increased glucose utilization by the peripheral tissues due to the $A$. marginale infection.

The significant rise in total bilirubin levels is coexisting with the appearance of RBCs infected with A. marginale (Coskun et al., 2012). The rise in total bilirubin levels may be attributed to $\mathrm{RBC}$ lysis by the reticuloendothelial system and probably liver cell damage (Coskun et al., 2012; Ashuma et al., 2013). The hyperbilirubinaemia observed could be hepatic due to the fact that the liver may be overwhelmed by the massive red cell destruction, hence could not conjugate the bilirubin and get it excreted from the system. 
In conclusion, this study demonstrated a noticeable prevalence and the presence of six blood parasites affecting cattle, with $A$. marginale and B. bigemina been the most prevalent blood parasites in the study area. About $60.0 \%$ of the studied cattle were infected with one or more blood parasites. There was a relationship between breed, age, body condition score, physiological status, PCV, presence of ticks, and the distribution of haemoparasites infections in cattle. Anaplasma marginale infection alters the haematological and biochemical parameters of infected White Fulani breed of cattle, which is the most predominant breed in Nigeria.

\section{ACKNOWLEDGEMENTS}

We express our heartfelt gratitude to the Director of Veterinary Services of the Kwara State Ministry of Agriculture and Natural Resources, for giving us permission to collect samples from slaughterhouses. We are also grateful to all the farm owners for allowing us to sample their cattle for the purpose of this study.

\section{CONFLICT OF INTEREST}

The authors declare that there is no conflict of interest among them.

\section{REFERENCES}

Abdullah DA, Ali MS, Omer SG, Ola-Fadunsin SD, Ali FF, Gimba FI. 2019. Prevalence and climatic influence on haemoparasites of cattle and sheep in Mosul, Iraq. J Adv Vet Anim Res, 6(4), 492-8.

Adedipe OD, Uwalaka EC, Akinseye VO, Adediran OA Cadmus SIB. 2014. Gastro-intestinal helminths in slaughtered cattle in Ibadan, south-western Nigeria. J Vet Med, Article ID 923561.https://doi.org/10.1155/2014/923561

Ademola IO, Onyiche TE. 2013. Haemoparasites and Haematological Parameters of Slaughtered Ruminants and Pigs at Bodija Abattoir, Ibadan, Nigeria. Afr J Biomed Res, 16(2), 101-5.

Adua MM, Idahor KO. 2017. Haematological Evaluation of Haemoparasites in Cattle and Goats Slaughtered at Lafia Abattoir, Nigeria. Asian J Biol, 4(1), 1-5.

Akande FA, Takeet MI, Makanju OA. 2010. Haemoparasites of cattle in Abeokuta, South West Nigeria. Sci World J, 5(4), 19-21.

Ashuma V, Sharma A, Singla LD, Kaur P, Bal MS, Batth BK, Juyal PD. 2013. Prevalence and haemato-biochemical profile of Anaplasmamarginaleinfection in dairy animals of Punjab (India). Asian Pac J Trop Med, 139-44. DOI: 10.1016/S19957645(13)60010-3

Atsuwe TS, Obisike VU, Azua ET, Imandeh GN. 2019. Prevalence of Tick Borne Haemoparasites in Some Breeds of Cattle and Goats Slaughtered in Some Abattoirs within Makurdi, Nigeria. J Appl Life Sci Int, 21(4), 1-5.
Bisimwa NP, Lugano RM, Bwihangane BA, Wasso SD, Kinimi E, Banswe G,Bajope B. 2018. Prevalence of Gastro-Intestinal Helminths in Slaughtered Cattle in Walungu Territory, South Kivu Province, Eastern Democratic Republic of Congo. Austin J Vet SciAnimHusb, 5(1), 1039-44.

Carter P. 2011. Tick Fever Centre. Innate susceptibility of various cattle breeds to tick fever disease caused by Babesia bovis and Anaplasma marginale. Sydney: Meat \& livestock Australia Limited.

Chauvin A, Moreau E, Bonnet S, Plantard O, Malandrin L. 2009. Babesia and its hosts: adaptation to long-lasting interactions as a way to achieve efficient transmission. Vet Res, 40, 37-54.

Cheesbrough M. 2006. District Laboratory Practice in Tropical Countries. (Part 1) $2^{\text {nd }}$ ed. University Press, New York.

Coskun A, Ekici OD, Guzelbektes H, Aydogdu U, Sen I. 2012. Acute phase proteins, clinical, hematological and biochemical parameters in dairy cows naturally infected with Anaplasma marginale. Kafkas Univ Vet Fakult Derg, 18(3), 497-502.

Enogiomwan IE, Offiong EE, Ukam UA. 2019. Haemoparasitic infection and haematological indices of cattle slaughtered for sale in Calabar, Nigeria. Int J Vet Sci Husb, 4(4), 7-11.

Ganguly A, Maharana BR, Ganguly I, Kumar A, Potliya S, Arora D, Bisla RS. 2018. Molecular diagnosis and haematobiochemical changes in Anaplasma marginale infected dairy cattle. Indian J Anim Sci, 88(9), 989-93.

Haque M, Jyoti I, Singh H, Rath SS. 2012. PCR-based detection of cryptic Trypanosoma evansi infection in cattle. Indian Vet J, 89(3), 19-21. 
Hunter-Cevera JC, Belt A. 1996. Maintaining cultures for biotechnology and industry, Academic Press.

Jonsson NN, Bock RE, Jorgensen WK. 2008. Productivity and health effects of anaplasmosis and babesiosis on Bos indicus cattle and their crosses, and the effects of differing intensity of tick control in Australia. Vet Parasitol, 155(1-2), 1-9.

Kaewthamasorn M, Wongsamee S. 2006. A preliminary survey of gastrointestinal and haemoparasites of beef cattle in the tropical livestock farming system in Nan Province, northern Thailand. Parasitol Res, 99(3), 306-8.

Kocan KM, de la Fuente J, Blouin EF, Garcia-Garcia JC. 2004 Anaplasmamarginale (Rickettsiales: Anaplasmataceae): Recent advances in defining host-pathogen adaptations of a tick-borne rickettsia. Parasitol, 129, 285-300.

Kubkomawa HI. 2017. Indigenous breeds of cattle, their productivity, economic and cultural values in Sub-Sahara Africa: A review. Int J Res Stud Agr Sci, 3(1), 27-43.

Lawal-Adebowale OA. 2012. Dynamics of ruminant livestock management in the context of Nigerian. Agr Sys, 4, 61-80.

Lasisi OT, Ojo NA, Otesile EB. 2002. Estimation of age of cattle in Nigeria using rostral dentition: Short communication. Trop Vet, 20(4), 204-8.

Mahiza MI. 2010. Prevalence of bovine haemoparasites and risk factors associated with Trypanosoma evansi infection in Malaysia. Universiti Putra Malaysia, Serdang, Malaysia.

Matovu E, Mugasa CM, Waiswa P, Kitibwa A, Boobo A, Ndung'u JM. 2020. Haemoparasitic Infections in Cattle from a Trypanosoma brucei rhodesiense Sleeping Sickness Endemic District of Eastern Uganda. Trop Med Infect Dis, 5, 24-33. doi:10.3390/tropicalmed5010024.

Meyer DJ, Harvey WJ. 2004. Veterinary Laboratory Medicine. $3^{\text {rd }}$ ed. London, UK: WB Saunders Co.

National Bureau of Statistics (NBS) 2016. Annual abstract of statistics. Federal Republic of Nigeria.

Okorafor UP, Nzeako SO. 2014. Prevalence of Haemoparasites of Cattle from Three Abattoirs in Ibadan Metropolis, Oyo State, Nigeria. Int J Sci Res Environ Sci, 2(7), 244-9.

Ola-Fadunsin SD. 2017a. Retrospective occurrence and risk factors associated with cattle parasitic infections in Osun State, Nigeria. Nig Vet J, 38(3), 195-209.

Ola-Fadunsin SD. 2017b. The diversity and epidemiology of bovine haemoparasites and their potential arthropod vectors in Peninsular Malaysia. PhD, Universiti Putra Malaysia, Serdang, Malaysia.

Ola-Fadunsin SD, Karaye PG, DogoGA. 2018. Haemoparasite fauna of domestic animals in Plateau State, North Central Nigeria. Bayero J Pure Appl Sci, 11(2), 156-61.

Ola-Fadunsin SD, Sharma RSK, Abdullah DA, GimbaFI,
Abdullah FFJ, Sani RA. 2021. The molecular prevalence, distribution and risk factors associated with Babesiabigemina infection in Peninsular Malaysia. Ticks Tick-borne Dis, 12, 101653. https://doi.org/10.1016/j.ttbdis.2021.101653

Ola-Fadunsin SD, Uwabujo IP, Halleed IN, Richards B. 2020. Prevalence and financial loss estimation of parasitic diseases detected in slaughtered cattle in Kwara State, North-central Nigeria. J Parasit Dis, 44(1), 1-9.

Qadeer MA, Gumel MA, Chessed G, Nganjiwa JI, Bernard K, Vandi P, Hakim D, Fadimatu U. 2015. A Cross Sectional Study on the Gastrointestinal and Haemoparasites of Trade cattle in Girei and Yola North Local Government Areas of Adamawa State, Nigeria. IOSR J Agr Vet Sci, 8(4), 3-5.

Sajid MS, Siddique RM, Khan SA, Iqbal Z, Khan MN. 2014. Prevalence and Risk Factors of Anaplasmosis in Cattle and Buffalo Populations of District Khanewal, Punjab, Pakistan. Glob Vet, 12(1), 146-53.

Sajid MS, Iqbal Z, Khan MN, Muhammad G, Iqbal MU. 2007. Effect of Hyalommaticks (acari: ixodidae) on milk production of dairy buffaloes (Bosbubalusbubalis) of Punjab Pakistan. Italian J AnimSci, 6, 939-41.

Shah-Fischer M, Say RR. 1989. Manual of Tropical Veterinary Parasitology. CAB International, Ox 108 DE, UK: Wallingford Oxon.

Shittu A, Zaharadeen MM, Fasina FO, Umaru MA, Abdullahi A. 2014. Classification of slaughtered animals and estimation of body condition scores during rainy season in Sokoto abattoir. Sokoto J Vet Sci, 12(2), 31-40.

Soulsby EJL. 1986. Helminths, Arthropods and Protozoa of Domestic Animals. 7th ed. London, Philadelphia and Toronto: Beilliere Tindall.

Tawah CL, Rege JEO. 1996. White Fulani cattle of West and Central Africa. Anim Genet ResourInf, 17, 127-46.

Taylor MA, Coop RL, Wall RL. 2016. Veterinary parasitology. 4th ed. Oxford, UK: Wiley-Blackwell.

Tembo S. 2012. Occurrence of tick-borne haemoparasites in cattle in the Mungwi district, Northern Province, Zambia. MSc, University of Pretoria, Pretoria, South Africa.

Thrall MA, Weiser G, Allison R, Campbell TW. 2012. Veterinary Hematology and Clinical Chemistry. 2nd ed. Iowa, USA: Wiley-Blackwell.

Weny G, Okwee-Acai J, Okech SG, Tumwine G, Ndyanabo S, Abigaba S, Goldberg T.L. 2017. Prevalence and risk factors associated with hemoparasites in cattle and goats at the edge of Kibale national park, Western Uganda. J Parasitol, 103(1), 69-74.

Yitayew D, Samuel D. 2015. Tick Borne Hemoparasitic Diseases of Ruminants: A Review. Adv Biol Res, 9(4), 210-24. 


\section{HEMOPARAZITI I HEMATO-BIOHEMIJSKI PROFILI POVEZANI S INFEKCIJAMA ANAPLASMA MARGINALE KOD STOKE U ILORINU, NIGERIJA}

\section{SAŽETAK}

Hemoparazitizam predstavlja glavni uzrok ekonomskih gubitaka u mnogim stočarskim državama u svijetu. Stoga je cilj ovog istraživanja odrediti prevalencu, obrasce infekcije i faktore rizika povezane sa hemoparazitskim infekcijama krava u Ilorinu, u Nigeriji. Drugi cilj je bio odrediti učinak infekcije Anaplasma marginale na hemato-biohemijske profile krava pasmine Bijeli Fulani. Od 478 naizgled zdravih krava sa farmi i iz klaonica prikupljeni su uzorci krvi. Prikupljeni uzorci krvi su podvrgnuti parazitološkim, hematološkim i biohemijskim analizama. Istraživanje je otkrilo prisustvo šest hemoparazita: Anaplasma marginale (25.3\%), Babesia bigemina (22.6\%), Babesia bovis (12.1\%), Trypanosoma sp. (8.6\%), Theileria sp. (7.1\%) i Anaplasma centrale (5.2\%). Učestalost udruženih infekcija pojedinim tipovima hemoparazita se smanjivao porastom broja udruženih infekcija. Vrsta, rezultat tjelesne kondicije, hematokrit i prisustvo krpelja su faktori rizika povezani signifikantno $(\mathrm{p}<0.05)$ sa pojavom infekcije uzrokovane $\mathrm{s} A$. marginale, dok su pasmina, starost, rezultat tjelesne kondicije, fiziološki status, hematokrit i prisustvo krpelja signifikantno povezni s infekcijom B. bigemina. Koncentracija hemoglobina, hematokrit, eritrociti, srednji korpuskularni volumen (MCV), srednja korpuskularna koncentracija hemoglobina (MCHC), albumin, urea, kalcij, glukoza, ukupni bilirubin i ukupni proteini su hematološki i biohemijski parametri koji su bili signifikantno povezani $(\mathrm{p}<0.05)$ s infekcijom A. marginale kod pasmine krava Bijeli Fulani. Podaci dobiveni ovim istraživanjem bi na koncu trebali poboljšati profitabilnost sektora stočarske proizvodnje u Nigeriji.

Ključne riječi: Babesia bigemina, faktori rizika, krv, Kwara State, prevalenca 